\title{
Participation in community intervention programmes and quality of life: findings from a multicenter study in Portugal
}

\author{
Maria Alice Martins da Silva Calçada Bastos ${ }^{1,2}$ (D) \\ Joana Mafalda Miguelote de Pinho Monteiro' (ID \\ Carla Maria Gomes Marques de Faria ${ }^{1,2}$ (D) \\ Maria Helena Pimente $e^{3,4}$ (ID \\ Sofia de Lurdes Rosas da Silva ${ }^{5,6}$ (D) \\ Carlos Miguel Figueiredo Afonso $^{3}$ (DD
}

\section{Abstract}

Objective: The present study aimed to analyze quality of life (QoL) in participants of community intervention programs (CIP) focused on healthy aging. Method: A multicenter cross-sectional study was carried out with 304 community-dwelling participants, aged 55 years old or more and living in three locations in Portugal. Half of these individuals $(\mathrm{n}=152)$ were involved in a CIP (intervention group). The intervention group was paired according to sex and age group with an equivalent number of participants $(n=152)$ that did not take part in a CIP (comparison group). Activities implemented in the CIP were grouped according to their nature: socio-recreational, educational/lifelong learning and physical activity. Data collection involved a Social Participation Questionnaire, the WHOQOL-Bref and the Satisfaction With Life Scale. Results: The CIP participants $(\mathrm{n}=152)$ had a mean age of 71.4 years $( \pm 5.4)$, were predominantly women $(75.0 \%)$, married $(65.4 \%)$, with fewer than five years of education $(71.7 \%)$ and a monthly family income of up to 750 euros (47.4\%). The intervention group had a significantly higher QoL in the physical domain than the comparison group $(p<0.03)$. Physical activity was the most frequently attended session in the CIP ( $\mathrm{n}=119,78.3 \%)$, in comparison with educational/ lifelong learning $(n=46,30.3 \%)$ and socio-recreational $(n=25,16.4 \%)$ activities. People
Keywords: Healthy Aging. Social Participation. Quality of Life. Health of the Elderly. Program Evaluation.

\footnotetext{
Instituto Politécnico de Viana do Castelo, Escola Superior de Educação. Viana do Castelo, Portugal

2 Centro de Investigação em Tecnologias e Serviços de Saúde (CINTESIS), Unidade de Investigação CINTESIS, Universidade do Porto. Porto, Portugal

3 Instituto Politécnico de Bragança, Escola Superior de Saúde. Bragança, Portugal

4 Instituto Politécnico de Bragança, Unidade de Investigação em Ciências da Saúde: Enfermagem (UICISA: E). Bragança, Portugal

5 Instituto Politécnico de Coimbra, Escola Superior de Educação. Coimbra, Portugal

${ }^{6}$ Universidade de Coimbra, Centro de Estudos Interdisciplinares do Século XX (CEIS 20). Coimbra, Portugal
}

Funding: Fundação para a Ciência e Tecnologia e Programa Operacional Competitividade e Internacionalização (SAICT-POL/23712/2016; POCI-01-0145-FEDER-023712)

The authors declare there are no conflicts of interest in relation to the present study. 
practicing physical activity in the CIP had a significantly higher QoL in the psychological, social relationships and environment domains $(p<0.05)$. Conclusion: Participation in the CIP was associated with QoL. Therefore, in line with the active aging framework, CIPs must be a part of public policy measures aimed at the QoL of the population.

\section{INTRODUCTION}

Due to their greater health vulnerability, creating opportunities for an active and healthy life is important for older people ${ }^{1}$. In line with previous studies ${ }^{2}$, aging is a dynamic process that occurs throughout life through a personal-context interrelationship. Several theoretical models have emphasized the importance of social participation and involvement in a healthy or successful aging (SA) process. For Rowe and $\mathrm{Kahn}^{3-}$ ${ }^{5}$ active involvement with life is one of the three components of a SA, which also includes cultivating close interpersonal relationships and engaging in meaningful and purposeful activities. More recently, these authors ${ }^{5}$ advocated for enhancing the skills and productive potential of older people, as well as creating opportunities for them to assume new social roles and responsibilities.

The Selective Optimization With Compensation model $^{6,7}$, meanwhile, perceives the individual as possessing self-regulatory mechanisms. Considering intraindividual plasticity and interpersonal variability in aging, Baltes and Baltes ${ }^{6}$ recommend strengthening reserve capacities through education, motivation, health promotion and social support. Better reserves (physical, mental and/or social) increase the likelihood of aging well.

In turn, the Preventive and Corrective Proactivity $(\mathrm{PCP})^{8-10}$ model associates aging with increased stress, recognizing an individual's ability to actively and effectively deal with age-related challenges. In line with Baltes ${ }^{6}$, this model emphasizes the importance of proactive self-regulation mechanisms, presenting the concepts of proactive preventive and corrective adaptations, including social behaviors (eg, helping others, mobilizing support, replacing roles). In keeping with Rowe and $\mathrm{Kahn}^{3}$, the PCP model highlights the maintenance of valued activities and relationships. In fact, the older adults themselves consider proactive involvement and interpersonal relationships as important factors in enjoying a $\mathrm{SA}^{11}$.
The importance of being socially involved also appears in the profile of active aging $(\mathrm{AA})^{12,13}$, with participation one of its four pillars. The ability to participate depends on health status and at the same time is central to health promotion, purpose in life and positive social relationships. Thus, it is recognized that being socially involved influences quality of life $(\mathrm{QoL})$. As such, policy measures need to be devised to provide opportunities for such involvement.

Despite the number of theories built around social participation, the concept is diffuse and lacks consensus, hindering communication between researchers, the creation of standardized measuring instruments and the comparability of research results ${ }^{14,15}$. For Scharlach and Lehning ${ }^{16}$, and in line with SA models, social involvement includes two subcomponents: social contact (personal relationships, social support) and social participation (meaningful social activities). Despite the aforementioned conceptual vagueness, there is a tendency to analyze the relationship between social participation and QoL as an indicator of successful aging. QoL is defined as individuals' subjective perceptions of their position in life in the context of the culture and value systems in which they live and in relation to their goals, expectations, standards and concerns ${ }^{17}$. There is evidence that participating in different social activities favors health-related QoL in the general population ${ }^{18}$ and specifically in the older population ${ }^{19}$.

Studies show that older adults who participate in social groups have significantly higher QoL than non-participants, namely in the physical, environmental and social relations domains of the WHOQoL-Bref and in the past/present/future activities, intimacy and socialparticipation facets of the WHOQOL-OLD ${ }^{20,21}$. Longitudinal studies show that participating in social activities leads to better $\mathrm{QoL}^{22,23}$, life satisfaction and self-esteem ${ }^{24}$ and reduces depressive symptoms ${ }^{23,24}$ in older adults. Moreover, this relationship seems 
to intensify with advancing age $\mathrm{e}^{22,25}$ and is stronger in older than younger people ${ }^{18}$. In a systematic review, Adams et al. ${ }^{26}$ found that several types of activity generate benefits in aging, highlighting social activities that can reduce the risk of social isolation, favor social and emotional support and social roles, among others. In turn, physical activity is associated with better QoL ${ }^{27-29}$, and its benefits go beyond the exercise itself, encompassing the social dimension, strengthening ties and occupying a relevant role in community life ${ }^{28,30}$.

In summary, while theory, research and policy indicate the relevance of social participation in the QoL and well-being of the older population, most relevant studies lack a comparison group. Based on the assumption that being socially involved brings gains in QoL and well-being, the present study aimed to compare the QoL of individuals participating in successful and healthy aging public community intervention programs (CIPs) with individuals who did not participate in such programs.

\section{METHOD}

The present study is part of a multi-center and multi-method research project (Aging, social participation and the early detection of dependence: skills for the Fourth Age (AgeNORTC)) carried out in three territories of Northern and Central Portugal (Viana do Castelo, Bragança and Coimbra/ Condeixa), involving Higher Education Institutions which provide education and training in Gerontology and Municipal Councils.

A comparative quantitative cross-sectional study that aimed to establish the baseline for analyzing changes in the aging process was performed. In this study of local public policy, social participation is understood to be systematic involvement in community initiatives - herein known as Community Intervention Programs (CIPs) - aimed at promoting active and successful aging. CIPs guide the operationalization of the AgeNORTC project, constituting the raw material for assessing the social participation/involvement of older people and its relationship with quality of life.
The present study included 152 participants involved in CIPs ( 50 per site) aged 55 to 84 years and living in the community, who formed the intervention group (IG) - the group under investigation. As this was a community-based study and randomly selecting participants on the basis of CIP registrants was impossible, the sample was selected via key partners (eg parish councils and associations) and direct contact with older people taking part in the CIP. For its part, the comparison group (CG; $n=50$ by location), paired with the previous group in terms of gender and age group, was selected through the family and neighborhood networks of participants, as well as key partners (eg municipal and parish councils, associations). Individuals who, although participating in CIPs, lived in care facilities for older adults were excluded. As an exploratory study it was thought important to detect an average difference in quality of life between pairs of 5\% (range $0-100 \%$ ), although there was no indication of variability. Assuming a standard deviation of between 15\% and $20 \%$, a sample of 50 pairs per site can detect this difference with a power greater than $85 \%$.

For data collection, a multidimensional gerontological evaluation protocol was used. The authors prepared a Sociodemographic and Social Participation Questionnaire with two sections: (1) sociodemographic aspects - 21 closed-ended questions and (2) aspects of participation in Community intervention Programs - six closedended questions.

Quality of life was assessed using the Portuguese version of the World Health Organization Quality of Life-Bref (WHOQoL-Bref) ${ }^{31}$. This instrument consists of 26 items, with five-point Likert-type response scales. The first two items assess overall quality of life (overall QoL) while the remainder are organized into four domains (Physical, Psychological, Social Relations and Environment). There is no overall instrument score. As recommended, the raw scores were converted to a 0-100 scale, with higher values indicating a better perception of quality of life. The Portuguese version of the WHOQoLBref $^{31}$ has high reliability values $(\alpha=0.92)$, with domains or facets ranging from a minimum of 0.64 (social relations domain) to 0.87 (physical domain). 
Regarding validity, the authors of the Portuguese version consider that it effectively discriminates people from the normal population from those with associated medical pathologies, both at the domain and general QoL level. These values are in line with those of the original version ${ }^{17}$.

Well-being was also assessed using the Portuguese version of the Satisfaction With Life Scale (SWLS) ${ }^{32}$. This scale provides access to participants' overall appreciation of their life, focusing on the judgement of the individual rather than a priori criteria. It consists of five items, with a seven point Likert type response scale. The higher the final score (0-35), the greater the degree of satisfaction with life. The Portuguese version has good internal consistency $(\alpha=0.78)$ and good validity indicators, namely significant correlations with self-efficacy, selfconcept, psychological maturity and social anxiety. These values are in line with the original version.

Information about the CIPs (Table 1) was collected through document analysis of reports and other written sources produced by local authorities.

Data collection was carried out by researchers and research fellows $(n=9)$ with the collaboration of undergraduate and masters students in Social Gerontology $(n=9)$ from the three Higher Education Institutions involved in the project. The entire team underwent previous training. The data collection protocol was administered at previously agreed sites (higher education institutions and community membership structures) between March and April 2018.

In terms of analysis strategies, a descriptive analysis of the data was carried out in relation to the sociodemographic characteristics of the participants and the variables under study. Through an initial descriptive analysis of the activities carried out in the CIP, three types were identified: (1) sociorecreational activities (dances, cinema, workshops and theater); (2) educational /lifelong learning activities (LLL) (aromatic and medicinal plant garden, literacy and computer science); and (3) physical activities (localized fitness and water aerobics). The relationships between the sociodemographic characteristics and involvement in different types of activity were explored using Chi-square tests. In order to test the effects of CIP participation on quality of life, comparative analyzes were performed with the Student's t-test for paired samples. In order to verify if there were statistically significant differences in the quality of life and well-being of the participants in the CIPs, based on the practice of different types of activities, Student's t-tests for independent samples were performed, comparing the practice vs. does not practice a certain type of activity groups.

In relation to ethical aspects, the present study was analyzed by the Ethics Committee of the School of Education in the Instituto Politécnico de Viana do Castelo (Polytechnic Institute of Viana do Castelo), which issued a favorable opinion. All participants were informed about the objectives and conditions of participation in the study, having signed the respective Informed Consent Form.

\section{RESULTS}

A total of 304 participants attending a CIP formed part of this study, of which 104 lived in Viana do Castelo, 100 in Bragança and 100 in Coimbra/ Condeixa, Portugal. These subsamples were divided into two groups: the intervention group (IG) and the comparison group (CG).

As shown in Table 1, the participants were mostly female $(75.0 \%)$ and aged $65-74$ years $(63.2 \%)$. However, individuals in the IG were aged between 60 and 84 years old [average $=71.4( \pm 5.4)$ ], while in the CG they were aged between 55 and 84 years old [average $=71.6( \pm 6.1)]$.

In both groups, the participants were predominantly married (IG $=64.5 \%$; $C G=69.7 \%$ ); with an education of between the $1^{\text {st }}$ and $4^{\text {th }}$ years of school ( $\mathrm{IG}=70.4 \%$; $\mathrm{CG}=67.1 \%)$; were retired $(\mathrm{IG}=92.5 \%$; $\mathrm{CG}=86.4 \%)$; had children $(\mathrm{IG}=92.6 \%$; $\mathrm{CG}=93.4 \%)$ and lived with their spouse $(\mathrm{IG}=61.8 \%$; $\mathrm{CG}=68.5 \%$ ). 


\begin{tabular}{|c|c|c|c|c|c|c|c|c|c|}
\hline 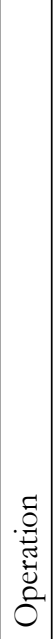 & 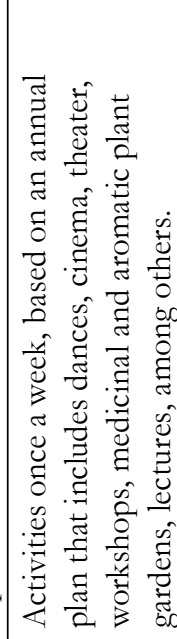 & 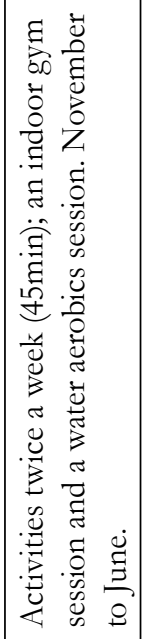 & 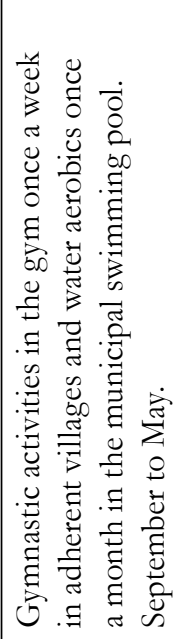 & 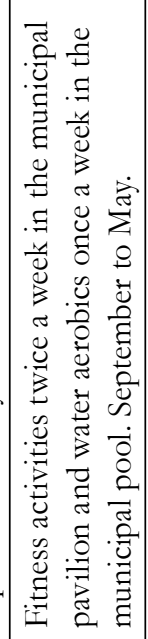 & 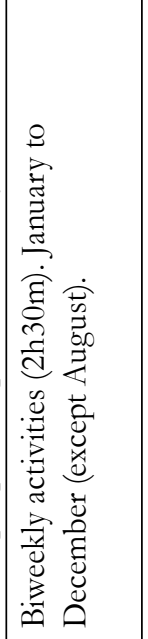 & 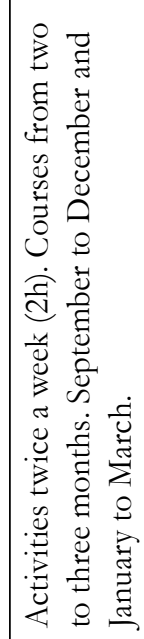 & 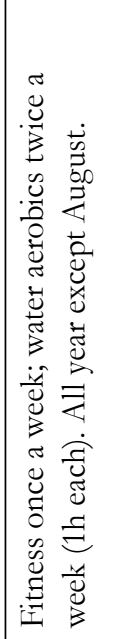 & 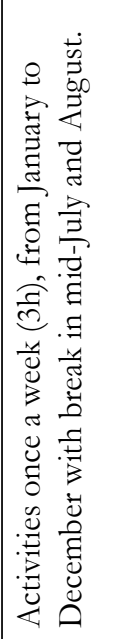 & 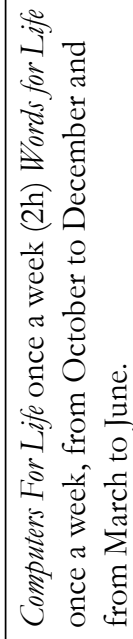 \\
\hline 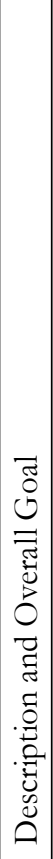 & 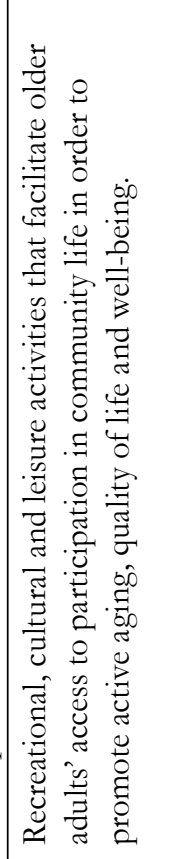 & 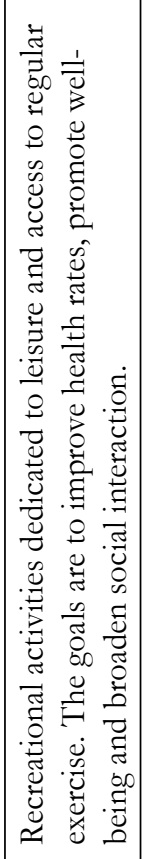 & 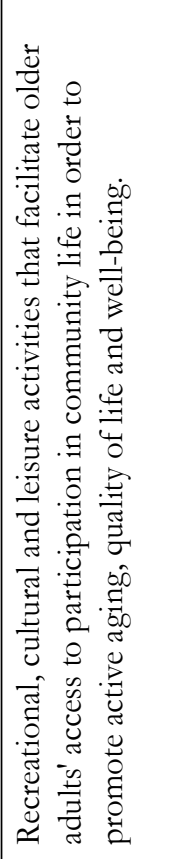 & 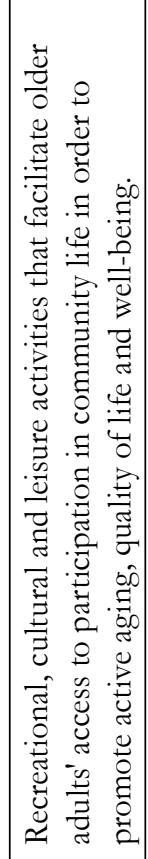 & 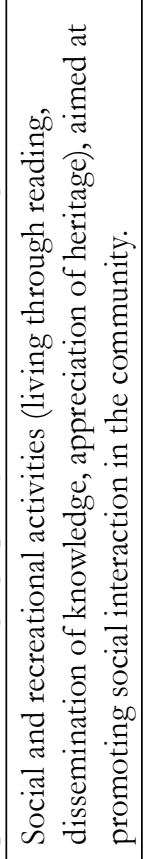 & 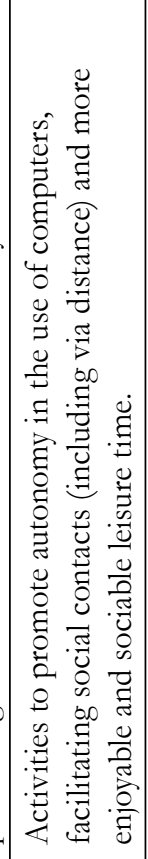 & 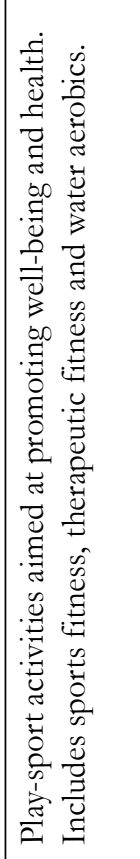 & 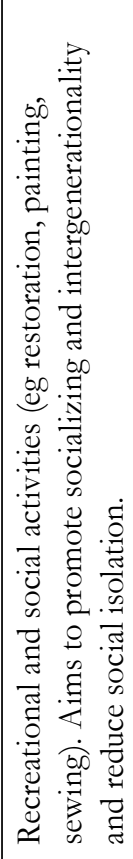 & 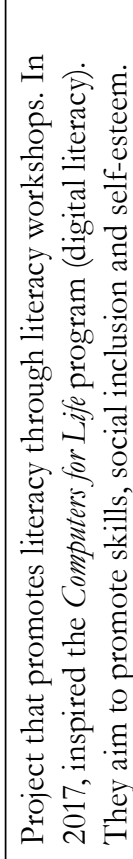 \\
\hline$\left|\begin{array}{l}0 \\
.0 \\
0 \\
0 \\
0 \\
0 \\
0 \\
0 \\
0 \\
0 \\
0\end{array}\right|$ & 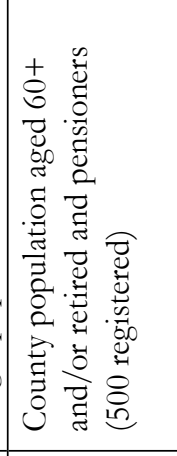 & 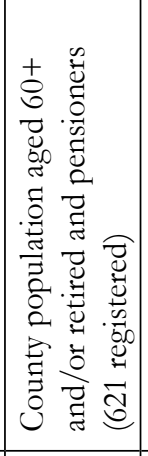 & 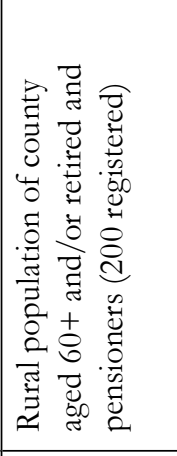 & 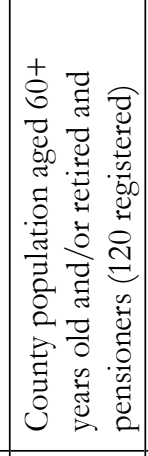 & 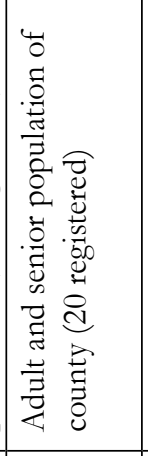 & 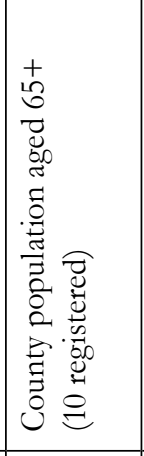 & 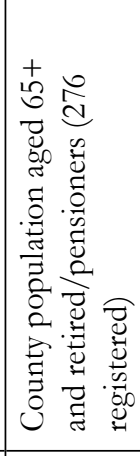 & 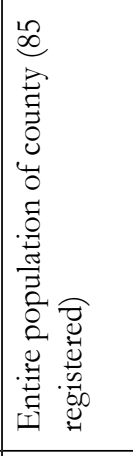 & 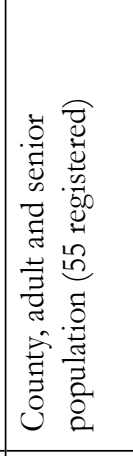 \\
\hline & 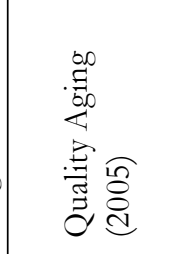 & 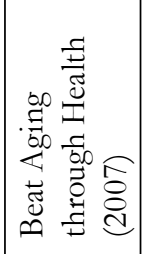 & 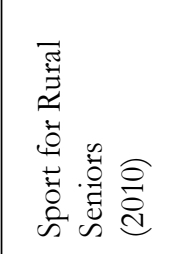 & 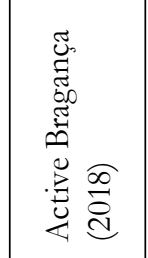 & 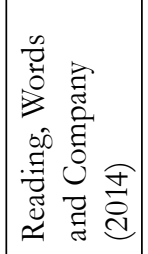 & 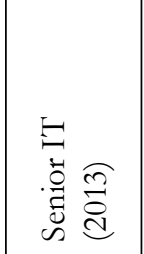 & 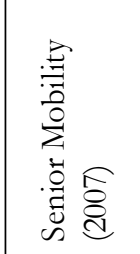 & 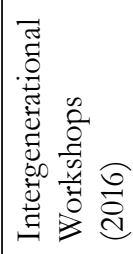 & $\begin{array}{l}0 \\
0 \\
0 \\
0 \\
0\end{array}$ \\
\hline & \multicolumn{2}{|r|}{ рр вนе! } & \multicolumn{2}{|c|}{ 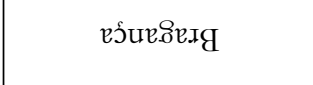 } & \multicolumn{5}{|c|}{ Iquilo? } \\
\hline
\end{tabular}


Table 1. Sociodemographic characterization of participants. Viana do Castelo, Bragança and Coimbra/Condeixa, Portugal, 2018.

\begin{tabular}{|c|c|c|c|}
\hline & IG $(n=152)$ & CG $(n=152)$ & $p$ \\
\hline 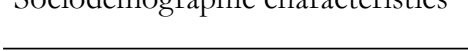 & $\mathrm{n}(\%)$ & $\mathrm{n}(\%)$ & \\
\hline Age - mean (standard-deviation) & $71.4( \pm 5.4)$ & $71.6( \pm 6.1)$ & 0.624 \\
\hline $55-64$ & $12(7.9)$ & $12(7.9)$ & \\
\hline $65-74$ & $96(63.2)$ & $96(63.2)$ & \\
\hline $75-84$ & $44(28.9)$ & $44(28.9)$ & \\
\hline Sex & & & 1 \\
\hline Female & $114(75.0)$ & $114(75.0)$ & \\
\hline Male & $38(25.0)$ & $38(25.0)$ & \\
\hline Marital Status & & & 0.566 \\
\hline Single & $7(4.6)$ & $5(3.3)$ & \\
\hline Married/Civil Partnership & $98(64.5)$ & $106(69.7)$ & \\
\hline Separated/Divorced & $8(5.3)$ & $4(2.6)$ & \\
\hline Widowed & $39(25.7)$ & $37(24.3)$ & \\
\hline Schooling (years) & & & 0.197 \\
\hline No schooling & $2(1.3)$ & $5(3.3)$ & \\
\hline $1^{\text {st }}-4^{\text {th }}$ & $107(70.4)$ & $102(67.1)$ & \\
\hline $5^{\text {th }}-6^{\text {th }}$ & $16(10.5)$ & $7(4.6)$ & \\
\hline $7^{\text {th }}-9^{\text {th }}$ & $7(4.6)$ & $13(8.6)$ & \\
\hline $10^{\text {th }}-12^{\text {th }}$ & $13(8.6)$ & $17(11.2)$ & \\
\hline Higher education & $7(4.6)$ & $8(5.3)$ & \\
\hline Professional status & & & 0.002 \\
\hline Employed & $4(2.7)$ & $18(12.2)$ & \\
\hline Unemployed & $7(4.8)$ & $2(1.4)$ & \\
\hline Retired & $136(92.5)$ & $127(86.4)$ & \\
\hline Professional sector & & & 0.649 \\
\hline Primary & $25(16.4)$ & $23(15.1)$ & \\
\hline Secondary & $35(23.0)$ & $33(21.7)$ & \\
\hline Tertiary & $73(48.0)$ & $69(45.4)$ & \\
\hline Domestic & $19(12.5)$ & $27(17.8)$ & \\
\hline Monthly Income & & & 0.056 \\
\hline Below $€ 250$ & $7(4.6)$ & $3(2.0)$ & \\
\hline From $€ 250$ to $€ 420$ & $25(16.6)$ & $23(15.4)$ & \\
\hline From $€ 421$ to $€ 750$ & $40(26.5)$ & $44(29.5)$ & \\
\hline From $€ 751$ to $€ 1000$ & $37(24.5)$ & $25(16.8)$ & \\
\hline From $€ 1001$ to $€ 2000$ & $32(21.2)$ & $29(19.5)$ & \\
\hline Over $€ 2000$ & $10(6.6)$ & $25(16.8)$ & \\
\hline \multicolumn{4}{|l|}{ Lives with } \\
\hline Spouse & $94(61.8)$ & $104(68.5)$ & 0.208 \\
\hline Alone & $42(27.6)$ & 29 (19.1) & \\
\hline Others & $16(10.5)$ & $19(12.5)$ & \\
\hline Sons/Daughters & $138(92.6)$ & $142(93.4)$ & 0.784 \\
\hline
\end{tabular}

IG: intervention group; CG: comparison group. 
In terms of life-long professional activity, using the classification of economic activities, there is a high frequency of tertiary workers, that is, those who worked in the services ( $\mathrm{IG}=48.0 \%$; $\mathrm{CG}=45.4 \%$ ). From an economic point of view, and considering that about two thirds of participants were living with others, household income was low, as about half of both groups earned up to $€ 750$ per month $(\mathrm{IG}=47.7 \% \mathrm{CG}=46.9 \%$ ).

Regarding quality of life and participation in the CIP, programs in three locations were analyzed: Viana do Castelo, Bragança and Coimbra/Condeixa. The municipal actions to promote the quality of life of the population assumes a different configuration according to location, in terms of intervention and functioning. For example, in the municipality of Bragança, the main focus of municipal policy measures is physical activities, while in Coimbra/ Condeixa and Viana do Castelo the municipal intervention is more heterogeneous, and also involves activities of a socio-recreational and educational/ LLL nature.

A comparative analysis of quality of life as a result of intervention group vs. comparison group (Table 2) shows that the participants in the CIP (IG) had a better quality of life in the physical domain $(p<0.03)$ than the non-participants (CG).

In the remaining quality of life domains, there was also a trend towards higher average values in the intervention group.
With regard to aspects of social participation in the intervention group, as shown in Table 3, localized fitness (67.1\%) and water aerobics (53.3\%) were the activities most carried out by the participants within the scope of the CIPs in the three territories under investigation. On average, each individual performed $1.9( \pm 1)$ activities, with $63.8 \%$ performing more than one. Regarding reasons for participating, maintaining health was most cited by respondents (66.4\%), followed by occupy time (44.7\%) and the opportunity to meet new people $(36.2 \%)$.

In terms of presence in the activities, almost all participants $(96.7 \%)$ considered themselves assiduous attendees. Average attendance at the CIPs was 51.6 months (approximately four years), although there was a wide dispersion of results at this level $( \pm 45.3$ months). Most of the participants had been attending these programs for a period of more than one year and less than five years $(50.7 \%)$.

Given the nature of the activities within the scope of the CIP, a greater number of people practiced physical activities than socio-recreational and educational/LLL activities. Although under different names, physical activity appeared in the programs of the three locations under investigation. It should also be noted that, in socio-recreational activities, there is a significantly higher percentage of women $(p<0.05)$ (Table 4$)$.

Regarding quality of life, considering practitioners and non-practitioners of each type of activity, physical activity is the greatest differentiating factor (Table 5).

Table 2. Comparison of quality of life between the group participating in community intervention programs (IG) vs. comparison group (CG). Viana do Castelo, Bragança and Coimbra/Condeixa, Portugal, 2018.

\begin{tabular}{llllll}
\hline WHOQoL-Bref & IG & CG & Dif. & $t$ & $p$ \\
& Mean $( \pm$ sd $)$ & Mean $( \pm$ sd $)$ & $( \pm$ sd $)$ & & Mean \\
\hline Overall QoL & $63.8( \pm 15.8)$ & $62.7( \pm 19.3)$ & $1.2( \pm 25.9)$ & 0.549 & 0.584 \\
Physical Domain & $67.5( \pm 15.4)$ & $63.5( \pm 16.6)$ & $4.1( \pm 22.0)$ & 2.278 & 0.024 \\
Psychological Domain & $71.0( \pm 15.2)$ & $70.3( \pm 13.6)$ & $0.4( \pm 20.3)$ & 0.417 & 0.677 \\
Social Relations Domain & $67.5( \pm 16.6)$ & $69.5( \pm 15.4)$ & $-2.0( \pm 22.9)$ & -1.091 & 0.277 \\
Environment Domain & $68.8( \pm 14.2)$ & $67.4( \pm 14.8)$ & $1.4( \pm 17.4)$ & 1.007 & 0.315 \\
\hline
\end{tabular}

Student's t-test for paired samples; sd: standard-deviation; QoL: quality of life; Mean Dif.: Difference of means. 
Table 3. Description of activities, reasons and attendance in community intervention programs ( $\mathrm{n}=152)$. Viana do Castelo, Bragança and Coimbra/Condeixa, Portugal, 2018.

\begin{tabular}{ll}
\hline Aspects of participation in CIP & $\begin{array}{l}\text { Participants } \\
\mathrm{n}(\%)\end{array}$ \\
\hline Activities performed & \\
Socio-recreational & $23(15.1)$ \\
Dances & $4(2.6)$ \\
Cinema & $19(12.5)$ \\
Workshops & $8(5.3)$ \\
Theater & \\
Education/LLL & $14(9.2)$ \\
Aromatic and Medicinal Plant Gardening & $1(0.7)$ \\
Literacy & $18(11.8)$ \\
Computing & \\
Physical activity & $102(67.1)$ \\
Fitness & $81(53.3)$ \\
Water aerobics & \\
\hline Reason for participating & $68(44.7)$ \\
Occupy time & $55(36.2)$ \\
Meet new people & $101(66.4)$ \\
Maintain health & $47(30.9)$ \\
Practice physical activities & $46(30.3)$ \\
Participate in activities they enjoy & $147(96.7)$ \\
\hline Attendance & \\
\hline Time spent in CIP (years) & $35(23.0)$ \\
Up to 1 & $77(50.7)$ \\
More than 1 to 5 & $32(21.1)$ \\
More than 5 to 10 & $8(5.3)$ \\
More than 10 &
\end{tabular}

LLL: Lifelong learning.

Table 4. Participation in activities of community intervention programs according to sociodemographic characteristics. Viana do Castelo, Bragança and Coimbra/Condeixa, Portugal, 2018.

\begin{tabular}{llll}
\hline $\begin{array}{l}\text { Sociodemographic } \\
\text { characteristics }\end{array}$ & $\begin{array}{l}\text { Socio-recreative activities } \\
(\mathrm{n}=25 ; 16.4 \%)\end{array}$ & $\begin{array}{l}\text { Educational/LLL activities } \\
(\mathrm{n}=46 ; 30.3 \%)\end{array}$ & $\begin{array}{l}\text { Physical Activity } \\
(\mathrm{n}=119 ; 78.3 \%)\end{array}$ \\
\hline Sex & & & \\
Female & $92.0 \%$ & $80.4 \%$ & $75.6 \%$ \\
Male & $8.0 \%$ & $19.6 \%$ & $24.4 \%$ \\
$P$ & $<0.05$ & 0.415 & 0.821 \\
\hline Age Group (years) & & & \\
$55-64$ & $0.0 \%$ & $6.5 \%$ & $8.4 \%$ \\
$65-74$ & $56.0 \%$ & $63.0 \%$ & $63.0 \%$ \\
$75-84$ & $44.0 \%$ & $30.5 \%$ & $28.6 \%$ \\
$P$ & 0.084 & 0.901 & 0.901 \\
\hline
\end{tabular}


Continuation of Table 1

\begin{tabular}{|c|c|c|c|}
\hline $\begin{array}{l}\text { Sociodemographic } \\
\text { characteristics }\end{array}$ & $\begin{array}{l}\text { Socio-recreative activities } \\
(\mathrm{n}=25 ; 16.4 \%)\end{array}$ & $\begin{array}{l}\text { Educational/LLL activities } \\
(\mathrm{n}=46 ; 30.3 \%)\end{array}$ & $\begin{array}{l}\text { Physical Activity } \\
(\mathrm{n}=119 ; 78.3 \%)\end{array}$ \\
\hline \multicolumn{4}{|l|}{ Marital Status } \\
\hline Married/Civil union & $48.0 \%$ & $58.7 \%$ & $65.5 \%$ \\
\hline Unmarried & $52.0 \%$ & $41.3 \%$ & $34.5 \%$ \\
\hline$P$ & 0.070 & 0.359 & 0.682 \\
\hline \multicolumn{4}{|l|}{ Years of Schooling } \\
\hline Up to 4 years & $80.0 \%$ & $78.3 \%$ & $68.1 \%$ \\
\hline 5 or more years & $20.0 \%$ & $21.7 \%$ & $31.9 \%$ \\
\hline$P$ & 0.340 & 0.178 & 0.521 \\
\hline \multicolumn{4}{|l|}{ Professional Status } \\
\hline Retired & $4.0 \%$ & $4.5 \%$ & $8.7 \%$ \\
\hline Non-retired & $96.0 \%$ & $95.5 \%$ & $91.3 \%$ \\
\hline$P$ & 0.691 & 0.506 & 0.457 \\
\hline \multicolumn{4}{|l|}{ Has Children } \\
\hline Yes & $95.5 \%$ & $95.3 \%$ & $92.4 \%$ \\
\hline$P$ & 1.000 & 0.512 & 1.000 \\
\hline \multicolumn{4}{|l|}{ Lives With Others } \\
\hline Yes & $64.0 \%$ & $69.6 \%$ & $74.6 \%$ \\
\hline$P$ & 0.332 & 0.694 & 0.271 \\
\hline \multicolumn{4}{|l|}{ Monthly Income } \\
\hline Up to $€ 750$ & $40.0 \%$ & $52.2 \%$ & $46.2 \%$ \\
\hline More than $€ 750$ & $60.0 \%$ & $47.8 \%$ & $53.8 \%$ \\
\hline$P$ & 0.513 & 0.482 & 0.694 \\
\hline \multicolumn{4}{|c|}{$\begin{array}{l}\text { Religion } \\
\text { (considers oneself religious) }\end{array}$} \\
\hline Yes & $100.0 \%$ & $100.0 \%$ & $95.5 \%$ \\
\hline$P$ & 0.600 & 0.102 & 1.000 \\
\hline
\end{tabular}

Chi-squared test.

Table 5. Quality of life and well-being according to the practice of different types of activities in community intervention programs. Viana do Castelo, Bragança and Coimbra/Condeixa, Portugal, 2018.

\begin{tabular}{|c|c|c|c|c|c|c|c|c|c|}
\hline & \multicolumn{3}{|c|}{ Socio-recreative activities } & \multicolumn{2}{|c|}{$\begin{array}{c}\text { Educational/LLL } \\
\text { Activities }\end{array}$} & \multicolumn{4}{|c|}{ Physical Activity } \\
\hline & Practices & $\begin{array}{l}\text { Does not } \\
\text { Practice }\end{array}$ & & Practices & $\begin{array}{l}\text { Does not } \\
\text { Practice }\end{array}$ & & Practices & $\begin{array}{l}\text { Does not } \\
\text { Practice }\end{array}$ & \\
\hline & $\begin{array}{l}\mathrm{n}=25 \\
\mathrm{M}\left(\underline{ \pm}_{\mathrm{sd}}\right)\end{array}$ & $\begin{array}{l}\mathrm{n}=127 \\
\mathrm{M}( \pm \mathrm{sd})\end{array}$ & $p$ & $\begin{array}{l}\mathrm{n}=46 \\
\mathrm{M}\left(\underline{ \pm}_{\mathrm{sd}}\right)\end{array}$ & $\begin{array}{l}\mathrm{n}=106 \\
\mathrm{M}( \pm \mathrm{sd})\end{array}$ & $p$ & $\begin{array}{l}\mathrm{n}=119 \\
\mathrm{M}(\underline{\mathrm{s} d})\end{array}$ & $\begin{array}{l}\mathrm{n}=33 \\
\mathrm{M}( \pm \mathrm{sd})\end{array}$ & $p$ \\
\hline \multicolumn{10}{|l|}{ WHOQoL-Bref } \\
\hline Overall QoL & $64.3( \pm 13.9)$ & $60.0( \pm 16.2)$ & 0.094 & $62.8( \pm 13.6)$ & $64.0( \pm 16.9)$ & 0.655 & $63.2( \pm 16.2)$ & $65.2( \pm 14.9)$ & 0.542 \\
\hline Physical Domain & $66.3( \pm 15.3)$ & $67.7( \pm 15.4)$ & 0.660 & $68.1( \pm 12.9)$ & $67.3( \pm 16.3)$ & 0.768 & $67.8( \pm 15.8)$ & $66.6( \pm 14.0)$ & 0.683 \\
\hline Psychological Domain & $72.3( \pm 8.4)$ & $70.8( \pm 16.2)$ & 0.482 & $67.7( \pm 15.2)$ & $72.5( \pm 15.1)$ & 0.075 & $72.3( \pm 14.4)$ & $66.4( \pm 17.2)$ & $<0.05$ \\
\hline Social Relations Domain & $68.3( \pm 13.2)$ & $67.3( \pm 17.2)$ & 0.781 & $64.1( \pm 14.5)$ & $68.9( \pm 17.2)$ & 0.099 & $69.3( \pm 16.4)$ & $61.1( \pm 15.5)$ & $<0.05$ \\
\hline Environment Domain & $68.5( \pm 11.2)$ & $68.8( \pm 14.7)$ & 0.911 & $65.8( \pm 12.8)$ & $70.1( \pm 14.6)$ & 0.082 & $70.3( \pm 14.2)$ & $63.5( \pm 12.9)$ & $<0.05$ \\
\hline Satisfaction With Life & $26.9( \pm 5.2)$ & $25.6( \pm 6.4)$ & 0.352 & $24.8( \pm 6.4)$ & $26.3( \pm 6.2)$ & 0.179 & $26.7( \pm 5.8)$ & $22.7( \pm 6.9)$ & $<0.05$ \\
\hline
\end{tabular}

Students T-test for independent variables; M: mean; sd: standard-deviation; QoL: quality of life. 
The analysis allows the statistically significant differences resulting from the practice of physical activity by the participants of the CIP to be identified, with practitioners of this type of activity having a better quality of life in the psychological, social relations and environment $(p<0.05)$ domains, as well better satisfaction with life $(p<0.05)$ than nonpractitioners.

\section{DISCUSSION}

The CIP participants had significantly higher quality of life values in the physical domain than non-participants. Furthermore, there was a tendency towards higher average values in the other quality of life domains (general, psychological, environment) in the CIP participant groups than in the groups that did not participate.

These results are in line with the study by Costa et al. ${ }^{28}$ in which older adults attending public physical exercise programs had a better quality of life than those who did not attend such programs in all domains of the WHOQoL-Bref and WHOQOLOld. Ferreti et al. ${ }^{27}$ also drew similar conclusions. Ribeiro et al. ${ }^{33}$, meanwhile, found that, in an urban context, physically active older adults had a better quality of life than those who were insufficiently active/sedentary. This difference was not found in the rural context, but a predominance of active people and higher levels of quality of life were found than in the urban environment, stressing that in rural areas older people benefit from the continuity of tasks related to agriculture and more opportunities for socialising.

Therefore, physical activity should be seen in a broad sense, because in addition to physical exercise, it involves the structuring of a routine and is practiced through social interaction, becoming a socializing activity. Costa et al..$^{28}$ underline that participation in group activities, even when aimed at physical activity, can favor social relationships, new emotional ties and feelings of significant inclusion in community life. The results also refer to the PCP model in which health promotion (eg, physical activity) and available social support appear as aspects that favor quality of life $e^{8-10}$.
Regarding the CIPs, there was diversity in the initiatives made available to the population by the municipalities, namely: recreational/cultural activities, recreational-sports activities, computer workshops and literacy workshops, among others. They also varied in terms of frequency, intensity, distribution across the territory and functioning. In terms of objectives, there seems to be uniformity, notably: (1) the promotion of AA, health, quality of life and well-being; and (2) contribute to participation in community life and social inclusion. In line with the study by Bárrios and Fernandes ${ }^{1}$, only one of the nine CIPs under analysis targets the entire population of the municipality, with the rest subjected to criteria such as age and/or the status of retired person/pensioner. These results are in keeping with systematic reviews of the topic, in which it was observed that interventions centered on AA are diverse and effective in promoting quality of life ${ }^{34}$.

As for the profile of the participants in the CIP, there was a predominance of women and of the age group of 65-74 years, which is in line with Neri and Vieira ${ }^{35}$, who found that being female and aged between 65 and 69 years old is associated with greater social involvement. It should be noted that some of the participants were involved in these actions for a long time, almost all consider themselves assiduous attendees and most practice more than one activity. Thus, for some, CIPs involve real commitment and involvement, constituting an important aspect of their daily lives. Continued adherence to interventions is considered an important factor for the effectiveness of programs ${ }^{34}$.

Among the activities performed in the CIPs, localized fitness (eg, muscle strength work, balance) and water aerobics are the most frequently available, which reflects the predominance and scope of interventions aimed at physical activity in the territories under investigation. It should be noted that maintaining health was the most commonly stated reason for participating in the CIPs, followed by occupying time and establishing new social ties. Thus, in line with the literature and the objectives established in the CIP, the participants seem to conceive the involvement in these activities as generating benefits in quality of life. In a critical review, Adams et al. ${ }^{26}$ observed that 
social participation influences well-being, and can do so in several ways. In participants of the CIP, a specific analysis of the type of activities performed shows significant differences between practitioners and non-practitioners of physical activity, with practitioners presenting significantly higher values of satisfaction with life and quality of life (psychological, social relations and environment domains). This means that practitioners of physical activity have a better quality of life than practitioners of other types of activities. If the Rowe and $\mathrm{Kahn}^{3}$ model is taken as a reference, effective successful aging, by being multifaceted, can be achieved through different components. The results of the present study point to the relevance of the biophysical system, but it is important to bear in mind that the body is not disconnected from psychosocial aspects, as previously mentioned.

Despite these findings, the present study has some limitations. Contrary to the initial plans, updated lists of CIP participants could not be accessed. On the other hand, although only age group and gender were used as criteria for pairing the sample, it was found that sociodemographic characteristics were very similar in both the intervention and the comparison group, such as, for example, the predominance of a low level of education and low monthly income.

It is recommended, therefore, that future studies on this theme include new sample groups with more differentiated attributes of sex, socioeconomic status and social involvement (eg, university educated older adults). As Adams et al. ${ }^{26}$ point out, a better understanding of the effects of social participation on well-being requires considering dimensions such as the meaning, context and requirement of activities. These aspects were addressed in the present study, namely in identifying the motivations and duration of involvement in the programs, but it is necessary to

\section{REFERENCES}

1. Bárrios MJ, Fernandes AF. A promoção do envelhecimento ativo ao nível local: análise de programas de intervenção autárquica. Rev Port Saúde Pública. 2014;32(2):188-96. go further. In addition, it is important to carry out a thorough analysis of the subjective experience of the aging process, using qualitative methods (provided for in this study), as well as an evolutionary analysis of the impact of social participation on the process of aging with quality, through longitudinal studies.

\section{CONCLUSION}

Participation in public community intervention programs favors quality of life, as participants had a better quality of life in the physical domain than non-participants. Participants who practiced physical activity also exhibited superior results in the physical, psychological, social relations and environment domains. Thus, to promote the quality of life of the population, the implementation of community intervention programs is recommended, in particular involving physical activities. The results also reveal the reduced participation of men, older seniors and groups with a higher socioeconomic status in these programs, aspects that researchers and policy makers must consider, especially as the impact of social participation on quality of life tends to intensify with age $^{22,25}$. A vision of aging as an ongoing process in life, with gains and losses, implies thinking about longevity through group actions, that is, through the collective life.

\section{ACKNOWLEDGEMENTS}

The AgeNortC project team would like to thank the Municipal Councils and those who participated in this study. Our thanks also extend to Dr. Liliana Parente, for her availability and collaboration in data collection.

Editd by: Ana Carolina Lima Cavaletti 
3. Rowe JW, Kahn RL. Successful aging. Gerontologist. 1997;37(4):433-40.

4. Rowe JW, Kahn RL. Successful Aging. Nova Iorque: Dell Publishing; 1998.

5. Rowe JW, Kahn RL. Successful Aging 2.0: conceptual expansions for the 21st century. J Gerontol Ser B Psychol Sci Soc Sci. 2015;70(4):593-6.

6. Baltes PB, Baltes MM. Psychological perspectives on successful aging: the model of selective optimization with compensation. In: Baltes PB, Baltes MM, editores. Successful aging: perspectives from the behavioural sciences. Cambridge: Cambridge University Press; 1990. p. 1-34.

7. Baltes PB, Lindenberger U, Staundinger UM. Life span theory in developmental psychology. In: Lerner RM, Damon W, editores. Handbook of child psychology: theoretical models of human development. Hoboken: John Wiley; 2006. p. 569-664.

8. Kahana E, Kahana B. Conceptual and empirical advances in understanding aging well through proactive adaptation. In: Bengston VL, editor. Adulthood and aging: research on continuities and discontinuities [Internet]. New York: Springer Publishing Company; 1996 [acesso em 14 jan. 2019]. p. 18-40. Disponível em: https://www.researchgate. net/publication/232522002_Conceptual_and_ empirical_advances_in_understanding_aging_well_ through_proactive_adaptation

9. Kahana E, Kahana B. Contextualizing successful aging: new directions in an age-old search. In: Settersten RA, editor. Invitation to the lifecourse: a new look at old age [Internet]. New York: Baywood Publishing Company; 2003 [acesso em 14 jan. 2019]. p. 225-255. Disponível em: https:// www.researchgate.net/publication/284482244_ Contextualizing_successful_aging_New_ directions_in_an_age-old_search

10. Kahana E, Kahana B, Lee J. Proactive approaches to successful aging: one clear path through the forest. Gerontology. 2014;60(5):466-74.

11. Lee JE, Kahana B, Kahana E. Successful aging from the viewpoint of older adults: development of a brief Successful Aging Inventory (SAI). Gerontology. 2017;63(4):359-71.

12. World Health Organization. Active ageing: a policy framework [Internet]. Genebra: WHO; 2002 [acesso em 18 jan. 2019]. Disponível em: http://apps.who.int/ iris/handle/10665/67215
13. Centro Internacional de Longevidade Brasil. Envelhecimento ativo: um marco político em resposta à revolução da longevidade [Internet]. Rio de Janeiro: Centro Internacional de Longevidade Brasil; 2015 [acesso em 18 jan. 2019]. Disponível em: http://ilcbrazil.org/portugues/wp-content/uploads/ sites/4/2015/12/Envelhecimento-Ativo-Um-MarcoPol $\%$ C3\%ADtico-ILC-Brasil_web.pdf

14. Levasseur M, Richard L, Gauvin L, Raymond E. Inventory and analysis of definitions of social participation found in the aging literature: proposed taxonomy of social activities. Soc Sci Med. 2010;71(12):2141-9.

15. Douglas H, Georgiou A, Westbrook J. Social participation as an indicator of successful aging: an overview of concepts and their association with health. Aust Health Rev. 2017;41(4):455-62.

16. Scharlach AE, Lehning AJ. Creating aging-friendly communities. New York: Oxford University Press; 2016.

17. Whoqol Group. Development of the WHOQOL: rationale and current status. Int J Ment Health. 1994;23(3):24-56.

18. Park HK, Chun SY, Choi Y, Lee SY, Kim SJ, Park E. Effects of social activity on health-related quality of life according to age and gender: an observational study. Health Qual Life Outcomes. 2015;13(140):1-9.

19. He Q, Cui Y, Liang L, Zhong Q, Li J, Li Y, et al. Social participation, willingness and quality of life: a population-based study among older adults in rural areas of China. Geriatr Gerontol Int. 2017;17(10):1593-1602.

20. Oliveira DA, Nascimento Júnior JRA, Bertolini SM, Oliveira DV. Participation of elderly in social groups: quality of life and functional capacity. Rev Rene. 2016;17(2):278-84.

21. Santos LF, Oliveira LM, Barbosa MA, Minamisava R, Souza BN, Nunes DP. Participação em grupo como recurso para promoção da saúde e qualidade de vida entre idosos. Rev Baiana Enferm. 2017;31(2): e17868 [12 p.].

22. Choi Y, Kwang-Sig L, Shin J, Kwon J, Park E. Effects of a change in social activity on quality of life among middle-aged and elderly Koreans: analysis of the Korean longitudinal study of aging (2006-2012). Geriatr Gerontol Int. 2017;17(1):132-41.

23. Hajek A, Brettschneider C, Mallon T, Enrst A, Mamone S, Wiese B, et al. The impact of social engagement on health-related quality of life and depressive symptoms in old age: evidence from a multicenter prospective cohort study in Germany. Health Qual Life Outcomes. 2017;15(1):1-8. 
24. Michèle J, Guillaume M, Alain T, Nathalie B, Claude F, Kamel G. Social and leisure activity profiles and well-being among the older adults: a longitudinal study. Aging Ment Health. 2017:1-7.

25. Nimrod G, Shrira A. The paradox of leisure in late life. J Gerontol Ser B Psychol Sci Soc Sci. 2016;71(1):106-11.

26. Adams KB, Leibbrandt S, Moon H. A critical review of the literature on social and leisure activity and wellbeing in later life. Ageing Soc. 2011;31(4):683-712.

27. Ferretti F, Beskow GC, Slaviero RC, Ribeiro CG. Análise da qualidade de vida em idosos praticantes e não praticantes de exercício físico regular. Estud Interdiscipl Envelhec [Internet]. 2015 [acesso em 29 jan. 2019];20(3):729-43. Disponível em: https://seer. ufrgs.br/RevEnvelhecer/article/view/41384

28. Costa FR, Rodrigues FM, Prudente CO, Souza IF. Qualidade de vida de idosos participantes e não participantes de programas públicos de exercícios físicos. Rev Bras Geriatr Gerontol. 2018;21(1):24-31.

29. Albuquerque AP, Borges-Silva F, Borges A, Pereira A, Dantas E. Physical activity: relationship to quality of life and memory in older people. Sci Sports. 2017;32(5):259-65.
30. Dias G, Mendes R, Serra e Silva P, Branquinho MA. Envelhecimento activo e actividade física. Coimbra: Escola Superior de Educação de Coimbra; 2014.

31. Canavarro MC, Simões MR, Vaz Serra A, Pereira M, Rijo D, Quartilho MJ, et al. WHOQOL-Bref: instrumento de avaliação da qualidade de vida da Organização Mundial de Saúde. In: Simões M, Machado C, Gonçalves M, Almeida L, editores. Avaliação psicológica. Instrumentos validados para a população portuguesa. vol. 3. Coimbra: Quarteto Editora; 2007. p. 77-100.

32. Neto F, Barros J, Barros A. Satisfação com a vida. In: Almeida S, Santiago R, Silva P, Oliveira L, Caetano $\mathrm{O}$, Marques, editores. A acção educativa: análise psico-social. Leiria: ESEL/APPORT; 1990. p. 91-100.

33. Ribeiro CG, Ferretti F, Sá CA. Qualidade de vida em função do nível de atividade física em idosos urbanos e rurais. Rev Bras Geriatr Gerontol. 2017;20(3):330-39.

34. Menichetti J, Cipresso P, Bussolin D, Graffigna G. Engaging older people in healthy and active lifestyles: a systematic review. Ageing Soc. 2016;36(10):2036-60.

35. Neri AL, Vieira LA. Envolvimento social e suporte social percebido na velhice. Rev Bras Geriatr Gerontol. 2013;16(3):419-32. 